\begin{tabular}{|l|l|l|l|l|l|}
\hline J. Tek. Ling. & Vol. 10 & No. 1 & Hal. 31-41 & Jakarta, Januari 2009 & ISSN 1441-318X \\
\hline
\end{tabular}

\title{
APLIKASI SIG UNTUK PENETAPAN KESESUAIAN WILAYAH PENERAPAN MEKANISASI PERTANIAN TANAMAN PANGAN
}

\author{
Mubekti \\ Peneliti di Pusat Teknologi Inventarisasi Sumberdaya Alam \\ Badan Pengkajian dan Penerapan Teknologi
}

\begin{abstract}
The study is the preliminary research aiming to apply the usefulness of the GIS system for classifying suitability of region to the agricultural mechanization. Simple basic theory of GIS and classification of agricultural mechanization were presented. Nine physical and non-physical parameters as limiting factors were defined and a weight of each parameter was calculated in order to know how far its effect to the agricultural mechanization practice. Data coming from several types, ie: numeric, vector and remote sensing (raster) were prepared to support the process. Two ordoes consisting of five classes were employed to extract suitability classification of each District in Jawa Barat dan Banten Province. The results show that ten districts are classified into suitable for applying agricultural mechanization, and the rest ten districts are classified into not suitable. Depending on the dynamic character of limiting factor, suitability class would possibly change along the time. Saveral conclusions and advices for improving research are given.
\end{abstract}

Kata Kunci: GIS, Kesesuaian Mekanisasi Pertanian

\section{PENDAHULUAN}

Kebijaksanaan pengembangan alat mesin pertanian khususnya mekanisasi pertanian adalah untuk menunjang kegiatan pra dan pasca panen dalam rangka meningkatkan produksi pangan. Hal tersebut dilaksanakan secara selektif antara lain petani sebagai faktor yang dominan dan faktor sosial ekonomi ${ }^{11}$. Kebijaksanaan mekanisasi pertanian juga tidak dapat terlepas dari kebijaksanaan pembangunan pertanian pada umumnya yaitu dapat berfungsi untuk meningkatkan pendapatan petani, menyediakan pangan secara mantap, membantu memperluas kesempatan kerja di pedesaan, turut mengerahkan pengembangan industri dan perkembangan ekonomi.
Pengembangan alat mesin pertanian di Indonesia dirasakan masih tersendatsendat, baik oleh masalah teknologi maupun oleh masalah sosial ekonomi masyarakat yang begitu beragam. Walaupun begitu, dilihat dari potensi produksi pertaniannya dan usaha untuk menjadikan pertanian berorientasi farming business, peluang untuk meningkatkan pemasyarakatan alat mesin pertanian di Indonesia masih terbuka lebar. Upaya-upaya yang dilakukan untuk mengatasi masalah tersebut antara lain adalah dengan melakukan pewilayahan mekanisasi pertanian selektif dengan maksud agar introduksi mekanisasi pertanian dapat mencapai sasaran yang diinginkan. 
Konsep pewilayahan mekanisasi secara selektif dengan empat wilayah pembagian telah lama dipakai sebagai acuan bagi pengembangan mekanisasi di Indonesia. Dalam hal ini wilayah pengembangan dibagi menjadi 4 tipe : (1). tipe I-A untuk wilayah lancar, (2). tipe I-B untuk wilayah siap, (3). tipe II untuk wilayah setengah siap, yaitu wilayah yang secara teknis dan sosial layak tetapi secara ekonomi tidak, dan (3). tipe III untuk wilayah terbatas, yaitu wilayah yang secara ekonomi dan sosial tidak layak untuk pengembangan alat mesin pertanian ${ }^{2}$.

Namun, masih banyak dijumpai kendala-kendala di lapangan terutama berkaitan dengan aspek sosial ekonomi budaya yang memang sangat bervariasi di tiap wilayah. Sehingga diperlukan konsep kesesuaian wilayah yang lebih baik untuk mengoptimalkan pengembangan mekanisasi dengan memasukkan parameter-parameter yang baru dan mendesain suatu alat bantu pengambil keputusan untuk memberikan informasi yang cepat dan terintegrasi.

Masalah tersebut memberikan peluang kepada sebuah sistem terpadu yang menggabungkan data-data bersifat spatial dan non spatial dalam bentuk Sistem Informasi Geografis (SIG) yang dapat memberikan informasi kesesuaian wilayah penerapan mekanisasi secara terintegrasi. Alat bantu ini dapat dibuat dengan memanfaatkan teknologi komputer. Dengan menggunakan teknologi SIG ini, maka informasi yang ditampilkan akan lebih baik, karena menggunakan data bersifat spatial (geografis). Kelebihan lain adalah kemudahan untuk memperbaharui (updating) hasil kesesuaian wilayah penembangan mekanisasi, karena format data dalam bentuk digital.

Konsep pengembangan mekanisasi selektif sebagai basis data akan dititikberatkan kepada selektif terhadap parameter-parameter geografis, ekonomi, sosial dan budaya, serta kelembagaan suatu wilayah. Hasil konsep pengembangan wilayah penerapan mekanisasi pertanian ini bersifat dinamis sesuai dengan perubahan parameter yang digunakan. Dengan memperhatikan kemudahan asesbilitas perolehan data, potensi dan kebijakan pemerintah daerah dalam pengembangan mekanisasi, dipilih daerah studi Propinsi Jawa Barat dan Banten sebagai pilot penerapan model untuk pemanfaatan teknologi SIG.

Tujuan dari perancangan ini adalah membuat suatu desain Sistem Informasi Geografis untuk kesesuaian wilayah penerapan mekanisasi pertanian di Jawa Barat dan Banten dengan menggunakan parameter fisiografis, ekonomi, sosial \& budaya, dan kelembagaan suatu wilayah.

Kegunaan hasil perancangan ini adalah Dapat menjadi alat bantu dan model dalam penerapan mekanisasi pertanian di suatu wilayah khususnya daerah Jawa Barat dan Banten melalui deskripsi data secara spatial.

\section{KERANGKA PEMIKIRAN}

Sistem Informasi Geografik (SIG) didefinisikan sebagai suatu sistem yang dirancang untuk membantu pengumpulan data, pengolahan data, analisis modelling data, serta penyajian data spatial/graphic dan data attribute/textual atau deskrips ${ }^{3}{ }^{3,4}$. Kedua jenis data tersebut disimpan dalam suatu sistem dinamakan basis data SIG, sistem basis data ini merupakan komponen utama yang harus tersedia. SIG adalah perangkat terintegrasi, berfungsi untuk membantu mempercepat proses perencanaan dan pengambilan keputusan yang melibatkan pengintegrasian data keruangan serta deskripsinya dalam lingkup penyelesaian suatu masalah, sebagai contoh proses koordinasi kegiatan perencanaan, serta penataan pengelolaan suatu kawasan lahan peruntukan ${ }^{5,6}$.

Secara garis besar, SIG adalah sistem yang mampu untuk menyusun, menyimpan 
, memanipulasi dan menampilkan informasi yang merujuk kepada geografis suatu wilayah. SIG ini akan mengadopsi teknik pengolahan data secara manual. Teknik pengolahan data tersebut kemudian dibuat logika komputer dengan menggunakan bahasa pemrograman yang terdapat dalam fasilitas perangkat lunak SIG. Dengan menggunakan perangkat lunak SIG datadata yang bersifat spatial/graphic akan digabungkan dengan data-data attribute kemudian diolah bersama-sama dan menghasilkan keluaran berupa sajian spasial geografis suatu wilayah yang dilengkapi legend sebagai deskripsinya.

Ari Sufyandi ${ }^{7}$, mengemukakan perlunya parameter-parameter baru untuk menyusun sebuah konsep kesesuaian wilayah penerapan mekanisasi pertanian yang selektif terhadap keadaan geografis, ekonomi, sosial budaya, dan kelembagaan suatu wilayah. Berdasarkan pengkajian di lapangan, disusun parameter-parameter yang dianggap paling berpengaruh terhadap proses intorduksi mekanisasi pertanian. Parameter-parameter tersebut meliputi aspek fisio-topografi (terdiri dari ; kemiringan lahan, topografi, luas baku sawah luas panen), demografi (terdiri dari ; jumlah keluarga tani, jumlah buruh tani, tingkat pendidikan), informasi (terdiri dari ; jumlah media massa, jumlah lembaga tani, jumlah kontak tani), dinamika sosial, dan sarana pendukung (terdiri dari ; jumlah bengkel baik logam atau automotif, penyalur suku cadang dan distributor alsin pertanian).

Aplikasi konsep kesesuaian wilayah penerapan mekanisasi dengan menggunakan SIG memerlukan suatu sistem basis data spatial (struktur topologikal) dan basis data non spasial / attribute. Kemudian SIG juga memerlukan basis model dan perangkat lunak. Hal yang perlu diperhatikan dalam pengelolaan basis data adalah kemampuan interaktif antar jenis data, dimana fungsi penelusuran data atribut dapat mengetahui posisi data spatial dan sebaliknya.
Di dalam basis data spatial terdapat peta landuse digital, yaitu peta yang menggambarkan penggunaan wilayah misalnya pemukiman, lahan pertanian, industri, kawasan terbuka dan sebagainya di Propinsi Jawa Barat dan Banten. Peta landuse bergeoreferensi pada suatu sistem koordinat pemetaan akan mewakili setiap daerah tingkat II di Jawa Barat dan Banten. Sedangkan pada basis data non spatiall attribute terdapat parameter-parameter : (1). Fisio-topografi (kemiringan Iahan/ topografi, luas baku sawah, luas panen), (2). Demografi (jumlah keluarga tani, jumlah buruh tani, pendidikan), (3). Informasi (jumlah media massa, jumlah lembaga tani, jumlah kontak tani), (4) Dinamika sosial, (5). Sarana pendukung (bengkel logam atau automotif, penyalur alsintani dan suku cadang).

Kesesuaian wilayah penerapan mekanisasi pertanian kemudian dilakukan dengan mengolah data yang bersifat spatial dan non spatial. . Hasilnya akan terdiri dari tiga katagori berdasarkan ordo, kelas, dan unit. Ordo akan memiliki dua wilayah pembagian mekanisasi pertanian yaitu wilayah yang sesuai dan tidak sesuai untuk penerapan mekanisasi pertanian di Jawa Barat dan Banten. Ordo untuk wilayah yang sesuai akan dibagi atas tiga kelas dan ordo untuk wilayah yang tidak sesuai akan dibagi atas dua kelas. Sehingga terdapat lima kelas kesesuaian wilayah penerapan mekanisasi pertanian di Jawa Barat dan Banten.

\section{BAHAN DAN METODE PEMODELAN}

Metode pemodelan akan menggabungkan metode analisis deskriptif dengan alat bantu perancangan SIG. Bahan dan peralatan yang digunakan dalam pengolahan SIG meliputi: (1)Hardware, yaitu PC Pentium-II dengan RAM 64 Mbyte dan meja digitizer dan (2) Software SIG Arc View versi 3.0 yang bekerja pada sistem operasi Window 97.

Ada 4 tahap yang harus dilakukan dalam perancangan SIG untuk kesesuaian 
wilayah penerapan mekanisasi pertanian di Jawa Barat ini yaitu : (1). pengumpulan data, (2). pemasukan data attribute, (3). pemasukan data spatial/grafis (4). analisis dan penyajian data. Aktivitas dari masingmasing tahapan adalah sebagai berikut:

1. Pengumpulan Data

- Mengumpulkan data sekunder dari sumber-sumber seperti BPS, BAPPEDA, DEPPEN Prop. Jawa Barat.

- Mengumpulkan data spasial sekunder yaitu peta landuse Propinsi Jawa Barat

- Mengumpulkan data spasial primer yaitu data citra satelit untuk koreksi peta landuse

2. Pemasukan data grafis

- Melakukan digitasi dan updating data geografis dari wilayah Propinsi Jawa Barat.

- Menyusun Topological Data Stucture (penyusunan data menurut topologi)
3. Pemasukan data Attribute

Data-data attribute yang akan dimasukkan adalah variabel-variabel yang termasuk ke dalam aspek fisiotopografi, demografi, informasi, dinamika sosial dan sarana pendukung yang terdiri dari : (1) Kemiringan lahan/ topografi, (2) Luas baku sawah, (3) Luas panen, (4) Jumlah keluarga tani, (5). Jumlah buruh tani, (6). Tingkat pendidikan, (7). Jumlah penduduk pengguna media, (8). Jumlah lembaga tani + jumlah kontak tani, (9). Jumlah Desa Swakarya + Desa Swasembada, dan (10). Jumlah bengkel (logam, automotif). Data attribute ini dimasukkan dalam kelas unsur layer yaitu landuse Jawa Barat untuk unsur lahan pertanian (sawah).

4. Analisis dan Penyajian Data

Analisis dilakukan berdasarkan kepada indikator yang mempengaruhi penerapan mekanisasi pertanian.

Formula yang akan dimasukkan kepada setiap indikator tersebut adalah:

- Kemiringan lahan $(T P)=\frac{\text { luas lahan dengan kemiringan } 0-8 \%}{\text { luas wilayah }}$

- Lahan pertanian (LLP) $=\frac{\text { luas baku sawah }}{\text { luas wilayah }}$

- Jumlah keluarga tani (JKT) $=\frac{\text { jumlah keluarga tani }}{\text { jumlah kepala keluarga }}$

- Jumlah buruh tani (JBT) $=\frac{\text { jumlah buruh tani }}{\text { jumlah penduduk }}$

- Tingkat pendidikan $(\mathrm{PD})=\frac{\text { jumlah penduduk } \mathrm{t} \text { amatan } \mathrm{SD} \text { ke atas }}{\text { jumlah penduduk }}$

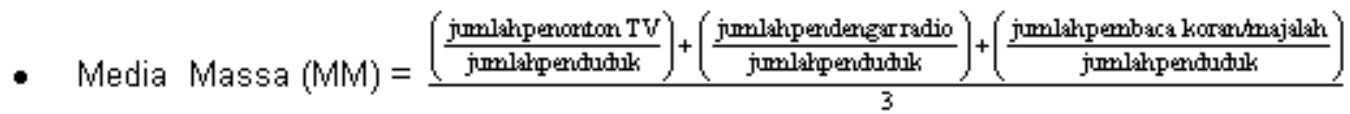

- Lembaga tani $\left((J L T)=\frac{\text { jumlah keluarga tani }}{\text { jumlah lembaga tani }+ \text { kontak } \tan i}\right.$ 
- Dinamika sosial (DS)= jumlah desa swakarsa + desa swasembada

- Sarana pendukung $(\mathrm{SP})=\frac{\text { luas sawah }}{\text { jumlah bengkel }+ \text { penyalur alsintani }}$

Selanjutnya dicari nilai terbesar dan nilai terkecilnya. Kemudian dicari selisihnya dan dari selisih tersebut dibagi oleh lima (range). Range terbesar akan diberi skor 5 dan range terkecil akan diberi skor 1 . Kekecualian untuk jumlah buruh tani yaitu diberi skor terbalik. Karena semakin sedikit buruh tani maka daerah tersebut akan lebih membutuhkan mekanisasi pertanian. Setelah diberi skor, setiap variabel akan dimasukkan nilai entropi yang nilainya diambil dari matriks skor tiap variabel. Hasilnya akan dijumlahkan dan akan didapat kesimpulan apakah daerah tersebut termasuk daerah yang cocok untuk mekanisasi pertanian (suitable) atau tidak cocok (unsuitable) dengan alasan yang dapat dijabarkan.

Adapun deskripsi lebih detail dari masing-masing kelas kesesuaian adalah sebagai berikut:

- Kelas S1: Sangat Sesuai (highly suitable), yaitu wilayah yang tidak mempunyai faktor penghambat yang berarti untuk diintroduksi mekanisasi pertanian

- Kelas S2: Cukup Sesuai (moderately suitable), yaitu wilayah yang mempunyai faktor pembatas yang agak serius untuk penerapan mekanisasi pertanian. Pembatas tersebut akan agak menghambata penggunaan peralatan mekanisasi pertanian

- Kelas S3:Sesuai Marginal (Marginally Suitable), yaitu wilayah dengan pembatas-pembatas yang serius untuk penerapan mekanisasi pertanian

- Kelas T1:Tidak Sesuai pada saat ini (currently not suitable), yaitu wilayah yang karena faktor pembatasnya sangat serius sehingga pada saat ini tidak memungkinkan untuk diterapkan mekanisasi pertanian

- Kelas T2: Tidak Sesuai Permanen (permanently not suitable), yaitu wilayah yang mempunyai faktor pembatas serius secara permanen, sehingga tidak sesuai diterapkan mekanisasi pertanian untuk selamanya.

Terdapat beberapa batasan yang digunakan dalam konsep kesesuaian wilayah penerapan mekanisasi pertanian ini, yaitu :

(1). Konsep kesesuaian wilayah penerapan mekanisasi pertanian yang digunakan dalam aplikasi SIG adalah konsep policy research yang bersifat tinjau dengan variabel-variabel yang mempengaruhi penerapan mekanisasi pertanian ditentukan berdasarkan data-data dari buku statistik saja. Skala peta yang digunakan adalah 1:250.000.

(2). Unit analisis yang digunakan adalah kabupaten.

(3). Katagori mekanisasi pertanian yang dimaksud dalam penelitian ini adalah alat-mesin pertanian yang bersifat movable untuk tanaman pangan, antara lain :

- Traktor : hand tractor, four-wheel-drivetractors dan two wheel tractors.

- Farmyard Manure Spreaders : mesin penghampar pupuk.

- Ground Crop Sprayers : mesin penyemprot pestisida.

Combine Harvester : Mesin pemanen 


\section{PEMODELAN SISTEM INFORMASI GEOGRAFIS}

Aplikasi SIG dalam kesesuaian wilayah penerapan mekanisasi pertanian dalam perancangannya membutuhkan entity relationship diagram (E-R) untuk menghindari terjadinya duplikasi data dalam menyusun sistem database di dalam SIG. Dalam rencana penerapan kesesuaian wilayah mekanisasi pertanian ini dipakai beberapa 'entity' yang terdiri dari (1) Petani dengan atributnya keluarga tani dan buruh tani, (2) Kabupaten dengan atribut luas wilayah, luas lahan pertanian, dan topografi, (3) Media Masa dengan atribut majalah, surat kabar, radio dan televisi, (4) Desa dengan atribut swadaya dan swasembada, (5) Lembaga Tani dengan atribut kontak tani, (6) Sarana Mekanisasi dengan atribut bengkel dan (7) Penduduk dengan atribut jumlah penduduk dan penduduk tamatan SD ke atas. Entity dan atribut yang tersebut diatas masih dapat dikembangkan lebih luas dan lebih detail, namun pada studi saat ini dibatasi seperti diatas.

Atribut-atribut tersebut diatas yang akan dijadikan parameter dalam penentuan kelas kesesuaian. Sebelum memformulasikan model GIS terlebih dahulu menyusun basis data dari setiap parameter dalam suatu file database yang berstruktur topologi (topological data structure). Penggambaran lebih jelas tentang diagram alir pengolahan data dalam GIS dapat dilihat dalam Gambar 1.

Setelah semua data masuk dalam sistem manajemen basis data, langkah selanjutnya adalah proses pengambilan keputusan dengan memakai bantuan sistem informasi geografi (GIS). Retrieval data adalah proses ekstraksi data didasarkan pada kriteria yang telah didefinisikan oleh pengguna ${ }^{8)}$.

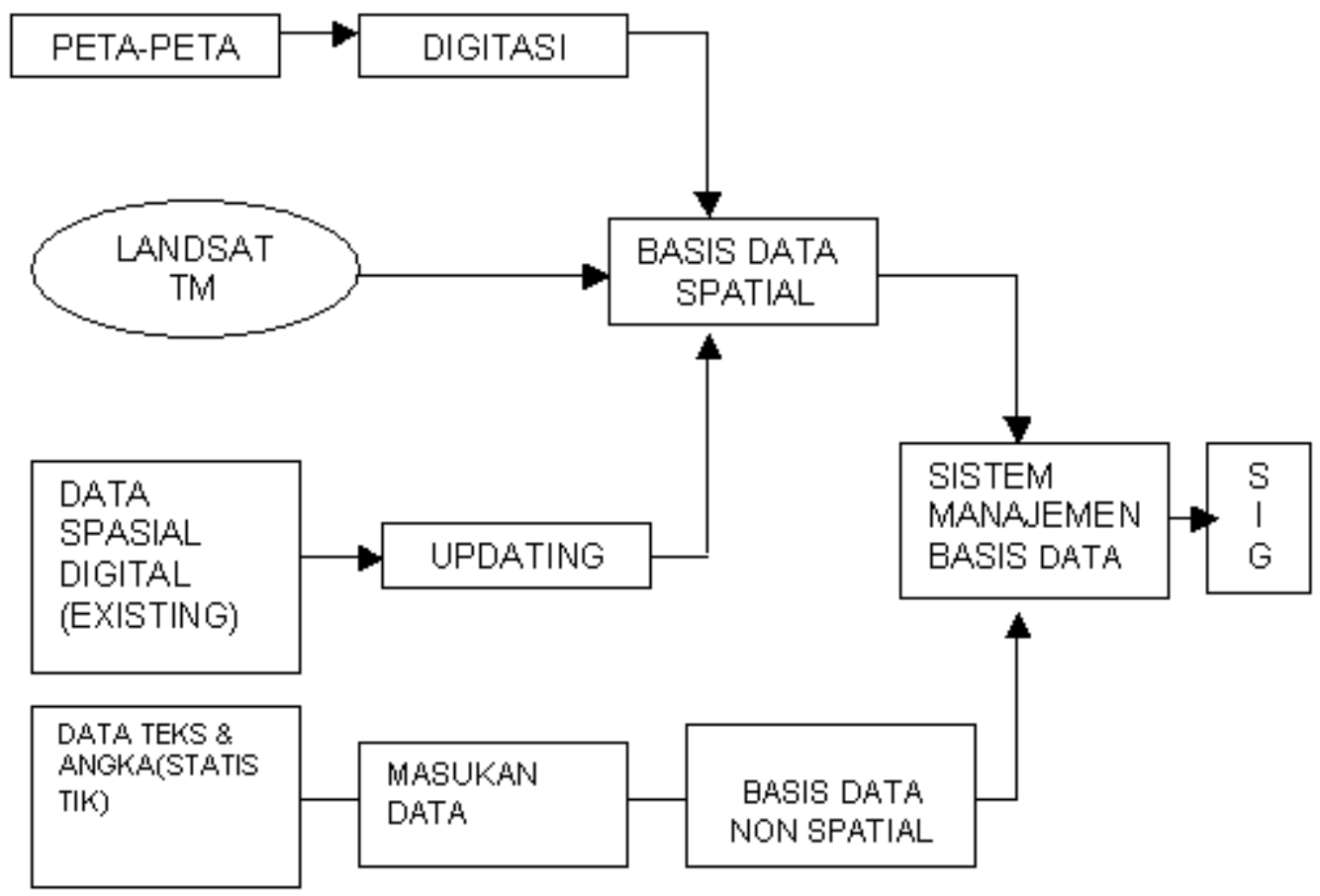

Gambar 1. Diagram Alir Pengolahan Data dalam GIS 
Sedangkan formulasi model yang dipakai dalam kesesuaian wilayah penerapan mekanisasi pertanian ini adalah:

$$
Y=\sum_{i=1}^{n} P_{i}
$$

Dimana

$$
\begin{aligned}
& \mathrm{Y}: \begin{array}{l}
\text { adalah kelas kesesuaian wilayah } \\
\text { penerapan mekanisasi pertanian }
\end{array} \\
& \mathrm{P}: \begin{array}{l}
\text { adalah parameter yang digunakan } \\
\text { dalam penentuan kesesuaian } \\
\mathrm{i}
\end{array} \\
& \mathrm{i}: \text { adayah penerapan mekanisasi } \\
& \mathrm{n}: \text { adalah jumlah parameter }=9
\end{aligned}
$$

Operasi pencarian data pada software ArcView GIS menggunakan pernyataan Select yang terdapat pada Structure Query Language (SQL). Pernyataan umum pada kesesuaian lahan adalah:
SELECT Field FROM Field WHERE [Table] AND[Table] = Conditions.

Dimana,

- $\quad$ Field adalah atribut dan spasial yang ditentukan

- Table adalah tabel database yang akan diakses

- Conditions adalah syarat dari atribut dan spasial.

Model pencarian data pada teknik pencarian dengan teknik Tabular Relational Data Base dengan kondisi sebagai berikut: Kabupaten Bandung yang landusenya adalah lahan pertanian (tegalan, ladang, dan sawah).

SELECT kab_bandung And use_dact WHERE landuse AND landagri.

Hasilnya seperti terlihat dalam Gambar 2.

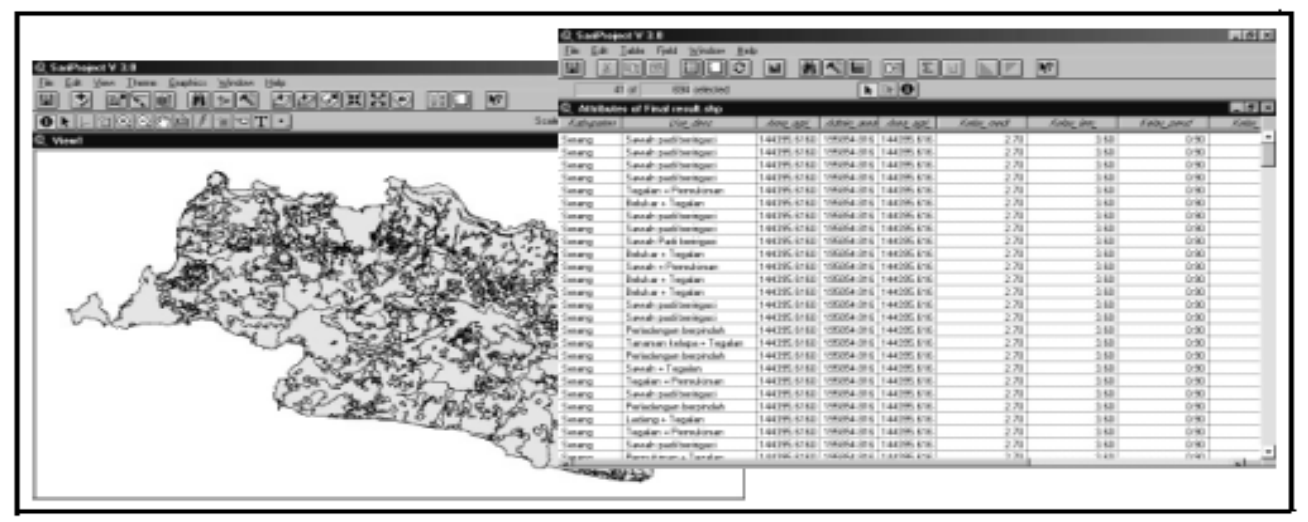

Gambar 2. Model GIS dengan teknik 'Relational Data'

\section{IMPLEMENTASI SIG DAN HASIL MODEL}

Hasil antara dari proses penerapan GIS untuk kesesuaian wilayah adalah penentuan nilai indek (scoring) untuk setiap parameter yang digunakan pada kabupaten-kabupaten di Jawa Barat. Seperti telah disebutkan terdahulu, bahwa scoring ini dilakukan dengan memberikan nilai indek 1 sampai 5 pada setiap parameter yang digunakan.
Nilai 1 berarti parameter yang bersangkutan menjadi faktor pembatas yang sangat serius terhadap penerapan mekanisasi pertanian, dan sebaliknya nilai 5 berarti parameter tersebut tidak merupakan faktor pembatas yang serius. Sebagai salah satu contoh dari skoring terhadap parameter adalah sebagai berikut (Tabel 1) 


\begin{tabular}{||l|c|c|}
\hline \multicolumn{1}{|c|}{ Parameter } & Range & $\begin{array}{c}\text { Nilai } \\
\text { indek }\end{array}$ \\
\hline Luas Lahan & $0.248-0.373$ & 1 \\
Pertanian(UP): & $0.374-0.499$ & 2 \\
Luas hahan & $0.500-0.625$ & 3 \\
pertanian/ luas & $0.626-0.751$ & 4 \\
milayah & $0.752-0.872$ & 5 \\
& & \\
\hline
\end{tabular}

Selanjutnya pemberian nilai indek tersebut diterapkan keseluruh Kabupaten yang ada di derah Jawa Barat. Hasil seperti yang terlihat pada Lampiran 1. Pemberian nilai indek antara 1 sampai 5 disesuaikan dengan jumlah kelas dalam klasifikasi kesesuaian yaitu ada tiga kelas Sesuai dan dua kelas Tidak Sesuai.

Setelah melakukan proses perhitungan score, langkah selanjutnya adalah mengkalikan score tersebut dengan nilai pembobotan yang didasarkan pada entropi dari masing-masing parameter. Perhitungan dan hasil selengkapnya entropi tidak disajikan dalam tulisan ini, namun hasil akhir pembobotannya adalah sebagai berikut:

(1) $\bar{\lambda}_{1}=11 \%$ untuk Luas Lahan Pertanian

(2) $\bar{\lambda}_{2}=8,4 \%$ untuk Jumlah Keluarga Tani

(3) $\bar{\lambda}_{3}=5 \%$ untuk. Jumlah Buruh Tani

(4) $\bar{\lambda}_{4}=9,5 \%$ untuk Pendidikan

(5) $\bar{\lambda}_{5}=9 \%$ Untuk Jumlah Lembaga Tani

(6) $\bar{\lambda}_{6}=2 \%$ untuk Media Massa

(7) $\bar{\lambda}_{7}=9,9 \%$ untuk Dinamika Sosial

(8) $\bar{\lambda}_{8}=20,5 \%$ untuk Sarana Pendukung

(9) $\bar{\lambda}_{g}=25 \%$ untuk Topografi.

Nilai $\bar{\lambda}$ berkisar antara 0 sampai $100 \%$ dan berkorelasi positif terhadap kesesuaian wilayah, dimana semakin besar nilai akan semakin baik pengaruhnya terhadap kesesuaian wilayah. Lampiran 2 merupakan tabel hasil penilaian kesesuaian terakhir yang merupakan perkalian nilai indek parameter dengan bobotnya. Selanjutnya total nilai yang diperoleh setiap Kabupaten akan diklasifikasikan sebagai berikut:

- $\quad 2.17979-2.54514=$ T2 $($ Tidak Sesuai selamanya)

- $2.54515-2.9105=$ T1 (Tidak Sesuai saat ini)

- $2.9106-3.27595=\mathrm{S} 3$ (Sesuai Marginal)

- $3.27596-3.64131=$ S2 (Cukup Sesuai)

- 3.64132-4.00677 = S1 (Sangat Sesuai)

Hasil selengkapnya Kelas Kesesuaian Wilayah Penerapan Mekanisasi Pertanian serta faktor pembatas dominan dapat dilihat pada Tabel 2. Dalam Tabel terlihat, bahwa terdapat 10 Kabupaten atau 50 persen dari Daerah Jawa Barat masuk dalam kelas sesuai untuk diterapkan mekanisasi pertanian, sedangkan 50 persen sisanya tidak sesuai.

Rincian kelas dari masing-masing Kabupaten di Jawa Barat adalah sebagai berikut:

1. Daerah yang tergolong ke dalam kelas S1 adalah Tangerang, Bekasi, Karawang, Subang, Bandung, dan Cirebon

2. Daerah yang tergolong ke dalam kelas S2 adalah Indramayu

3. Daerah yang tergolong ke dalam kelas S3 adalah Serang, Bogor, dan Majalengka.

4. Daerah yang tergolong ke dalam kelas T1 adalah Cianjur, Sumedang, Garut, Tasikmalaya, Ciamis, dan Kuningan.

5. Daerah yang tergolong ke dalam kelas T2 adalah Pandeglang, Lebak, Purwakarta, dan Sukabumi.

Angka 1 dalam Tabel menunjukkan faktor pembatas yang paling dominan mempengaruhi kesesuaian wilayah. Parameter-parameter yang digunakan dalam studi bersifat dinamis kecuali topografi, sebagai konsekuensinya kelas kesesuaian juga bersifat dinamis. Apabila ada salah satu atau lebih parameter yang berubah secara mencolok, maka klasifikasi kesesuaian harus diperbaharui. Kalau dilihat dalam Tabel, terlihat bahwa faktor pembatas 
dominan bersumber dari Topografi dan Sarana Pendukung. Topografi merupakan faktor pembatas alam yang bersifat permanen. Kemiringan lahan yang curam menyebabkan sulitnya berbudidaya pertanian tanaman pangan serta merupakan kendala dalam operasionalisasi mesinmesin pertanian. Sedangkan sarana pendukung bersifat dinamis, sehingga apabila ada peningkatan, misalnya peningkatan jumlah bengkel dan penyalur alat dan mesin pertanian akan dapat memperbaiki kelas kesesuaian wilayah untuk diintroduksi mekanisai pertanian.

Sajian informasi kesesuaian wilayah secara spasial untuk daerah Jawa Barat terlihat dalam Gambar 2. Informasi spasial tersebut menunjukkan bahwa sebagian besar daerah yang masuk dalam katagori Sesuai terletak di jalur Pantura (Pantai Utara Jawa) kecuali Bandung. Hal tersebut sesuai dengan kondisi dilapangan, dimana daerah Pantura merupakan hamparan luas yang datar dan merupakan sentra produksi padi nasional. Bandung walau terletak di altitut tinggi tetapi merupakan daerah datar yang sangat cocok untuk budidaya tanaman pangan. Sebaliknya untuk daerah yang mempunyai topografi bergelombang sampai bergunung yang secara geografis terletak di jalur tengah dan selatan Jawa Barat masuk dalam katagori Tidak Sesuai. Kendala utama daerah ini adalah budidaya pertanian dilakukan pada lahan sempit dengan sistem terasering sehingga mesin pertanian akan sulit bergerak dari satu tempat ke tempat lainnya.

\section{KESIMPULAN DAN SARAN}

Berdasarkan kepada perancangan yang telah dilakukan maka dapat ditarik kesimpulan bahwa dengan menggunakan SIG, proses analisis Kesesuaian Wilayah Penerapan Mekanisasi Pertanian Tanaman Pangan di Jawa Barat dapat berlangsung lebih cepat dan lebih akurat. Hal-hal yang dipertimbangkan sangat membantu dalam analisis adalah sebagai berikut :

Tabel 2. Kelas kesesuaian wilayah penerapan mekanisasi pertanian dan faktor pembatas dominan

\begin{tabular}{|c|c|c|c|c|c|c|c|c|c|c|}
\hline \multirow{2}{*}{ Kabupaten } & \multirow{2}{*}{ Kelas } & \multicolumn{9}{|c|}{ Faktor pembatas dominan } \\
\hline & & LLP & $J K T$ & $\mathrm{~J} \mathrm{JT}$ & PD & JLT & $\mathrm{MM}$ & DS & $\mathrm{SP}$ & TP \\
\hline Serang & 83 & & & & 1 & & & & & 1 \\
\hline Pandenglang & T2 & 1 & & & & & & & & 1 \\
\hline Lebak & T2 & & & & & & & & 1 & 1 \\
\hline Tangerang & S1 & & 1 & & & & & & 1 & \\
\hline Bekasi & S1 & & & & & & & 1 & & \\
\hline Karawang & S1 & & & & & & & & & \\
\hline Purwakarta & T2 & & & 1 & & & & 1 & 1 & 1 \\
\hline Subang & S1 & & & & & & & & & \\
\hline Bogor & S3 & & & & & & & & 1 & \\
\hline Sukabumi & T2 & & & & & 1 & & & 1 & 1 \\
\hline Cianjur & T1 & & & & & & & & 1 & 1 \\
\hline Bandung & S1 & & & & & & & & & \\
\hline Sumedang & T1 & & & & & & & & 1 & \\
\hline Garut & T1 & & & & & & & & 1 & 1 \\
\hline Tasikamalaya & T1 & 1 & & & & & & & 1 & 1 \\
\hline Ciamis & T1 & 1 & & & & & & & & 1 \\
\hline Cirebon & S1 & & & & & & & & & \\
\hline Kuningan & T1 & & & & & & & & 1 & \\
\hline Majalengka & 83 & & & & & 1 & & & 1 & \\
\hline Indramayu & 52 & & & & 1 & & & & & \\
\hline
\end{tabular}


- Dalam proses analisis Kesesuaian Wilayah Penerapan Mekanisasi, petapeta tematik dalam bentuk digital (Landuse dan Administration Boundary) sangat membantu baik dalam kecepatan maupun dalam keakuratan analisis.Deskripsi dalam bentuk 2 dimensi yang ditampilkan memiliki kualitas yang lebih baik.

- Dalam proses Updating Database, aplikasi SIG memberikan banyak kemudahan yang berkaitan dengan manajemen database yang terpadu (Topological Structure Database) sehingga proses proses pengintegrasian maupun penambahan data dapat dilakukan dengan sistematis.

- Hasil kesesuaian wilayah penerapan mekanisasi pertanian tanaman pangan di Jawa Barat menunjukkan bahwa 50 persen (10 Kabupaten) masuk dalam katagori Sesuai, sedangkan 50 persen sisanya masuk dalam katagori Tidak Sesuai.

- $\quad$ Sifat dari keseauaian wilayah ini tidak permanen. Untuk tingkat global, jangka waktu revisinya akan lebih lama dibanding dengan tingkat lokal.

Dari hasil Perancangan SIG untuk Kesesuaian Wilayah Penerapan Mekanisasi Pertanian Tanaman Pangan di Jawa Barat ini dapat diberikan beberapa saran-saran antara lain :

1. Perlunya penelitian tentang parameterparameter lain yang mendukung konsep Kesesuaian Wilayah Penerapan Mekanisasi Pertanian sehingga dapat lebih menjadikan operasionalisasi konsep ini semakin baik di lapangan.

2. Revisi kesesuaian perlu dilakukan seiring dengan dinamika perameternya.

3. Aplikasi SIG untuk pertanian harus lebih dikembangkan sehingga dapat menjadi sebuah sistem informasi terpadu pertanian yang dapat membantu pengembangan agrobisinis dan agroindustri sehingga tujuan pertanian yang berorientasi Farming Bussiness dapat tercapai

\section{DAFTAR PUSTAKA}

1. Sugianto, 1988. Tinjauan Permasalahan Pengembangan Alsin Pertanian di Indonesia. Sub Direktorat Alsintan Departemen Pertanian RI.

2. Soedjatmiko, 1988. Prospek dan Permintaan Pasar Alat Mesin Pertanian di Indonesia. Makalah Seminar Alsintani/PAMERINDO Jakarta.

3. Aronoff, Stan., 1989. Geographic Information System : A Management Perspective. WDL Publications, Ottawa, Canada.

4. Bolstad, P. 2005. GIS Fundamentals, A First Text on Geographic Information Systems, 2nd ed., Eider Press, White Bear Lake, Minnesota

5. Barrough, PA., 1988. Principle Of Geographical Information System For Land Resources Assessment. Oxford University Press, New York

6. Clarke, Keith C., Parks, Bradley O., and Michael P. Crane (eds.). 2002. Geographic Information Systems and Environmental Modeling, Fourth International Conference on Integrating Geographic Information Systems and Environmental Modeling, Banff, Canada, September, 2000, Prentice-Hall Inc., Upper Saddle River, New Jersey

7. Ari Sufyandi, 1998. Konsep Pengklasifikasian Kesesuaian Wilayah Penerapan Mekanisasi Pertanian. Makalah Seminar dan Kongres Perhimpunan Teknik Pertanian, Yogyakarta

8. Aronoff, Stan., 1989. Geographic Information System : A Management Perspective. WDL Publications, Ottawa, Canada 
Lampiran 1. Tabel nilai indek parameter per Kabupaten

\begin{tabular}{||l|c|c|c|c|c|c|c|c|c||}
\hline \multicolumn{1}{|c|}{ Kabupaten } & LLP & JKT & JET & PD & JLT & MM & DS & SP & TP \\
\hline Serang & 4 & 4 & 5 & 1 & 4 & 3 & 4 & 3 & 1 \\
\hline Pandenglang & 1 & 4 & 5 & 2 & 4 & 3 & 3 & 2 & 1 \\
\hline Lebak & 3 & 5 & 2 & 2 & 3 & 3 & 2 & 1 & 1 \\
\hline Tangerang & 5 & 1 & 4 & 5 & 5 & 5 & 2 & 1 & 5 \\
\hline Bekasi & 4 & 2 & 5 & 5 & 4 & 5 & 1 & 2 & 5 \\
\hline Karawang & 4 & 5 & 5 & 3 & 3 & 5 & 2 & 4 & 4 \\
\hline Purwakarta & 2 & 3 & 1 & 4 & 4 & 4 & 1 & 1 & 1 \\
\hline Subang & 4 & 2 & 5 & 3 & 5 & 4 & 2 & 3 & 4 \\
\hline Gogor & 2 & 3 & 5 & 5 & 2 & 4 & 5 & 1 & 3 \\
\hline Sukabumi & 2 & 4 & 5 & 3 & 1 & 3 & 3 & 1 & 1 \\
\hline Cianjur & 3 & 5 & 5 & 4 & 2 & 4 & 2 & 1 & 1 \\
\hline Eandung & 2 & 3 & 5 & 5 & 3 & 5 & 4 & 5 & 2 \\
\hline Sumedang & 2 & 4 & 5 & 5 & 4 & 5 & 2 & 1 & 2 \\
\hline Garut & 2 & 4 & 5 & 4 & 3 & 4 & 4 & 1 & 1 \\
\hline Tasikamalaya & 1 & 5 & 5 & 5 & 2 & 4 & 4 & 1 & 1 \\
\hline Ciarnis & 1 & 5 & 5 & 5 & 4 & 4 & 3 & 2 & 1 \\
\hline Cirebon & 3 & 2 & 5 & 3 & 4 & 4 & 4 & 2 & 5 \\
\hline Kuningan & 3 & 2 & 5 & 4 & 5 & 4 & 3 & 1 & 2 \\
\hline Majalengka & 4 & 5 & 5 & 5 & 1 & 4 & 2 & 1 & 3 \\
\hline Indramayu & 4 & 5 & 4 & 1 & 3 & 3 & 2 & 2 & 5 \\
\hline
\end{tabular}

Lampiran 2. Tabel hasil penilaian kesesuaian setiap Kabupaten berdasar nilai indek parameter dan pembobotannya

\begin{tabular}{|c|c|c|c|c|c|c|c|c|c|c|}
\hline Kabupaten & \begin{tabular}{|c|} 
LLP \\
0.11762
\end{tabular} & \begin{tabular}{|c|} 
JKT * \\
0,08696
\end{tabular} & 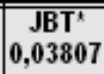 & \begin{tabular}{c|}
$P^{*}$ \\
0,09813
\end{tabular} & $\begin{array}{c}\mathrm{JLT}^{*} \\
\mathbf{0 , 0 9 2 7 7}\end{array}$ & $\begin{array}{c}\text { SP } \\
0,007174\end{array}$ & $\begin{array}{c}\mathrm{TP}^{*} \\
0,24509\end{array}$ & $\begin{array}{c}M M^{*} \\
0.13085\end{array}$ & \begin{tabular}{|l|}
$D S{ }^{*}$ \\
0.11877
\end{tabular} & $\begin{array}{l}\text { TOTAL } \\
\text { SCORE }\end{array}$ \\
\hline Serang & 0.47048 & 0.34784 & 0.19035 & 0.09813 & 0.37108 & 0.3587 & 0.24509 & 0.13085 & 0.47508 & 2.68760 \\
\hline Pandeglang & $|0.11762|$ & 0.34784 & 0.19035 & 0.19626 & 0.37108 & 0.28696 & 0.24509 & 0.13085 & 0.35631 & 2.24236 \\
\hline Lebak & $\mid 0.35286$ & 0.4348 & 0.11421 & 0.19626 & 0.27831 & 0.28696 & 0.24509 & 0.13085 & 0.23754 & 2.27688 \\
\hline Tangerang & $\mid 0.58810$ & 0.08696 & 0.15228 & 0.39252 & 0.46385 & 0.07174 & 1.22545 & 0.52340 & 0.23754 & 3.74184 \\
\hline Bekasi & $\mid 0.47048$ & 0.17392 & 0.19035 & 0.49065 & 0.37108 & 0.28696 & 1.22545 & 0.65425 & 0.11877 & 3.98191 \\
\hline Kerawang & 0.47048 & 0.4348 & 0.19035 & 0.29439 & 0.27831 & 0.3587 & 0.98036 & 0.5234 & 0.23754 & 3.76833 \\
\hline Purwakarta & 0.23524 & 0.26088 & 0.03807 & 0.29439 & 0.37108 & 0.28696 & 0.24509 & 0.39255 & 0.11877 & 2.24303 \\
\hline Subang & 0.47048 & 0.17392 & 0.19035 & 0.29439 & 0.46385 & 0.3587 & 0.98036 & 0.39255 & 0.11877 & 3.44337 \\
\hline Bogor & 0.23524 & 0.26088 & 0.19035 & 0.49065 & 0.18554 & 0.14348 & 0.73527 & 0.39255 & 0.59385 & 3.22781 \\
\hline Sukaburni & 0.23524 & 0.34784 & 0.19035 & 0.29439 & 0.09277 & 0.28696 & 0.24509 & 0.13085 & 0.35631 & 2.17980 \\
\hline Cianjur & 0.35286 & \begin{tabular}{|l|l|}
0.4348 \\
\end{tabular} & 0.19035 & 0.39252 & 0.18554 & 0.14348 & 0.24509 & 0.2617 & 0.23754 & 2.44388 \\
\hline Bandung & 0.23524 & 0.26088 & 0.19035 & 0.49065 & 0.27831 & 0.3587 & 0.49018 & 0.5234 & 0.47508 & 3.30279 \\
\hline Sumedang & 0.23524 & 0.34784 & 0.19035 & 0.49065 & 0.37108 & 0.28696 & 0.49018 & 0.5234 & 0.23754 & 3.17324 \\
\hline Garut & 0.23524 & 0.34784 & 0.19035 & 0.39252 & 0.27831 & 0.14348 & 0.24509 & 0.39255 & 0.47508 & 2.70046 \\
\hline Tasikmalaya & $\mid 0.11762$ & \begin{tabular}{|l|l|}
0.4348 \\
\end{tabular} & 0.19035 & 0.49065 & 0.18554 & 0.28696 & 0.24509 & 0.39255 & 0.47508 & 2.81864 \\
\hline Ciannis & 0.11762 & 0.4348 & 0.19035 & 0.49065 & 0.37108 & 0.3587 & 0.49018 & 0.39255 & 0.35631 & 3.20224 \\
\hline Cirebon & 0.35286 & 0.17392 & 0.19035 & 0.29439 & 0.37108 & 0.3587 & 1.22545 & 0.39255 & 0.47508 & 3.83438 \\
\hline Kuningan & 0.35286 & 0.17392 & 0.19035 & 0.39252 & 0.46385 & 0.3587 & 0.49018 & 0.39255 & 0.35631 & 3.17124 \\
\hline Majalengka & 0.47048 & \begin{tabular}{|l|l|}
0.4348 \\
\end{tabular} & 0.19035 & 0.49065 & 0.09277 & 0.3587 & 0.73527 & 0.39255 & 0.23754 & 3.40311 \\
\hline Indramayu & $\mid 0.47048$ & \begin{tabular}{|l|l|}
0.4348 \\
\end{tabular} & 0.15228 & 0.09813 & 0.27831 & 0.3587 & 1.22545 & 0.13085 & 0.23754 & 3.38654 \\
\hline
\end{tabular}

Aplikasi Sig untuk Penetapan... J.Tek.Ling. 10 (1): 31 - 41 